\title{
The efficacy and safety comparison of first- line chemotherapeutic agents (high-dose methotrexate, doxorubicin, cisplatin, and ifosfamide) for osteosarcoma: a network meta-analysis
}

\author{
Bin Zhang ${ }^{1}$, Yan Zhang ${ }^{1 *}$, Rongzhen $\mathrm{Li}^{2}$, Jiazhen $\mathrm{Li}^{1}$, Xinchang $\mathrm{Lu}^{1}$ and Yi Zhang ${ }^{1}$
}

\begin{abstract}
Background: Osteosarcoma, a primary malignant bone tumor derived from mesenchymal tissue, is the most common type of pleomorphic tumor that occurs in children and adolescents. The aim of this study was to compare the efficacy and safety of high-dose methotrexate (M), doxorubicin (D), cisplatin (C), and ifosfamide (I) in the management of osteosarcoma.

Methods: Electronic databases including PubMed, Cochrane Library, and Embase database were searched for studies published from when the databases were established to July 13, 2019. The network meta-analysis was performed using software R 3.3.2 and STATA version 41.0 after demographic and outcome data extraction. The ranks based on probabilities of interventions for each outcome were performed. In addition, the consistency of direct and indirect evidence was assessed by node splitting.

Results: The network meta-analysis results revealed that MDCI had a significant lower hazard risk of overall survival $[\mathrm{MDCl}$ vs MDC: $H R=0.74,95 \% \mathrm{Crl}(0.23,0.87) ; \mathrm{MDCl}$ vs $\mathrm{DC}: \mathrm{HR}=0.60,95 \% \mathrm{Crl}(0.16,0.92)]$. In addition, $\mathrm{MDCl}$ had a clearly longer progression-free survival time than that of $\mathrm{DC}[\mathrm{MDCl}$ : $\mathrm{HR}=0.88,95 \% \mathrm{Crl}(0.46,0.98)]$. No significant difference was detected in MDC and DC in OS, PFS, and AEs. The probabilities of rank plot showed that MDCI ranked first in OS (73.12\%) and PFS (52.43\%). DC was the best treatment in safety, ranked first (75.43\%).

Conclusions: $\mathrm{MDCl}$ showed its superiority among all chemotherapeutic agents in relation to efficacy and safety, followed by MDC. In addition, MDCI was associated with an increased risk of AEs. According to our analysis, DC was less effective but safer for MDC and MDCl.
\end{abstract}

Keywords: Osteosarcoma, Chemotherapy, Methotrexate, Doxorubicin, Cisplatin, Ifosfamide, Network meta-analysis

\section{Background}

Osteosarcoma, a primary malignant bone tumor derived from mesenchymal tissue, is the most common type of pleomorphic tumor that occurs in children and adolescents $[1,2]$. Treatment of this bone cancer, the third most common malignancy in children and adolescents, was once

\footnotetext{
* Correspondence: zhangy741104@163.com

${ }^{1}$ Department of Orthopedics, The First Affiliated Hospital of Zhengzhou University, No. 1 Jian she East Road, Erqi District, Zhengzhou City 450052, Henan Province, People's Republic of China

Full list of author information is available at the end of the article
}

mainly amputation, with very limited efficacy [3]. However, since the mid-1970s, multidrug chemotherapy, including high-dose methotrexate, doxorubicin, cisplatin, and ifosfamide, and surgical strategies have increased the 5 -year overall survival rate of OS to $70-80 \%$ [4]. Nowadays, available several opinions are available for osteosarcoma, including systemic chemotherapy, targeted drug therapy, immunotherapy, radiotherapy, and experimental therapy [5]. Chemotherapy, a basic treatment, has been widely performed in clinical practice for many years. The common chemotherapy agents for osteosarcoma include high-dose 
methotrexate, doxorubicin, cisplatin, ifosfamide, gemcitabine, decitabine, etoposide, and vincristine [6, 7].

The mainstream chemotherapeutic agents include methotrexate, doxorubicin, cisplatin, and ifosfamide, which were the first-line chemotherapy agents approved by the NCCN Guidelines [8]. Since the introduction of chemotherapy, single-agent treatment of osteosarcoma is considered inadequate [9-11]. The majority of osteosarcoma treatment and research protocols is based on a combination of two or more of only four drugs: doxorubicin, cisplatin, methotrexate, and ifosfamide [12]. Therefore, eligible studies that compared doxorubicin + cisplatin (DC), methotrexate + doxorubicin + cisplatin (MDC), and methotrexate + doxorubicin + cisplatin + ifosfamide (MDCI) for osteosarcoma treatment were meaningful for our research. These three chemotherapy regimens recommended by the NCCN Guidelines Version 1.2020 have been the commonly used chemotherapy treatment for osteosarcoma patients [13].

Even though all preferred regimens have been widely used for many years, we still do not know the absolute role of each component of multidrug chemotherapy [14]. Therefore, which one is the optimal choice for use in osteosarcoma patients has still not been established. Also, it is difficult to say which chemotherapeutic regimen is superior. Furthermore, no systematic review and meta-analysis that accurately compared these three chemotherapy regimens including all the above four agents [15]. By adopting the new technology of network meta-analysis, we can achieve detailed comparisons, with direct and indirect evidence. Therefore, in the present protocol of network meta-analysis, we will aim to evaluate the efficacy and safety of the first-line chemotherapeutic agents for the treatment of osteosarcoma.

\section{Methods}

\section{Searches}

This network meta-analysis was performed in accordance with the guideline of Preferred Reporting Items for Systematic Reviews and Meta Analyses. We conducted a search of PubMed, Cochrane Library, and Embase databases from inception to July 2019. The Mesh terms and related synonym included "Osteosarcoma," "OS," "Osteosarcomas," "Osteosarcoma Tumor," "chemotherapy," "Doxorubicin," "Methotrexate," "Ifosfamide," "Cisplatin," "randomized controlled trial," "RCT," and "randomly" were combined in the search strategy. We also manually searched the reference lists of related publications such as reviews and meta-analyses. The eligibility of the results retrieved was carefully examined with the use of EndNote software. Irrelative publications were removed by scanning the title, abstract, as well as the full texts.

\section{Inclusion criteria}

In general, trials were considered eligible when they met the following criteria: (1) randomized controlled trials (RCTs), (2) all patients were diagnosed with osteosarcoma, and (3) two or more interventions among DC, $\mathrm{MDC}$, and MDCI were compared.

\section{Exclusion criteria}

The following criteria were used for exclusion: (1) other therapies were included, such as related receptor targeted therapy, immunotherapy, vaccine therapy, and radiotherapy; (2) insufficient data relating to treatments, outcomes of patients, and study design; (3) outcome data were unable to combined with other studies; and (4) letters, case reports, comments, meta-analysis, review and meeting abstracts, animal experiment, and basic research.

\section{Quality assessment}

Two independent reviewers assessed methodological quality with Cochrane Handbook for Systematic Reviews Interventions version 5.1.3. For every included trial, the following criterions were evaluated and given a grade of low, medium, or high risk bias: random sequence generation, allocation concealment, blinding of participants and personnel, blinding of outcome assessment, incomplete outcome data, selective reporting, and other biases. Any disagreements on risk of bias ratings were regularly resolved through discussion by the two reviewers or by a consultation with a third reviewer.

\section{Data extraction}

Two investigators performed the data extraction from qualified studies independently. The extracted data were as follows: first author's name, country, journal, publication year, trail name, total study sample size, sample sizes of each treatment group, follow-up duration, and relevant clinical outcomes. The main outcomes included overall survival (OS), progression-free survival (PFS), and severe adverse events (AEs). OS was defined as the time from random assignment to death. PFS was defined as the time from randomization to first appearance of radiographic or clinical progression or death. Severe AEs were defined as grades $\geq 3$. We analyzed the total number of severe AEs and the most common reported events including leukopenia, thrombocytopenia, red blood cell (RBC) transfusion, platelet (PLT) transfusion, granulocyte colonystimulating factor (G-CSF) transfusion, and hospitalization.

\section{Data synthesis and analysis}

The network meta-analysis was performed for each clinical outcome using R 3.3.2 software and STATA version 14.0 (Stata Corp LP, College Station, TX). The OS and PFS were treated as time-to-event variables, thus, these parameters were expressed as hazard ratio (HR) with 
95\% credible intervals (CI) for each study. In some studies, the HR with 95\% CrI was not given directly but was presented as Kaplan-Meier curves; we calculated the values using the software of Engauge Digitizer 9.6 and the method provided by Tierney et al. [16]. If the survival curve was unavailable too, we estimated these values with the formulation $\log (\mathrm{HR})=(\mathrm{T} 1+\mathrm{T} 2) 2$ / $[(\mathrm{E} 1+\mathrm{E} 2) \mathrm{T} 1 \mathrm{~T} 2] . \mathrm{E} 1$ and E2 are the numbers of events and $\mathrm{T} 1$ and $\mathrm{T} 2$ are the numbers of patients randomly assigned in each group [17]. Odds ratio (OR) with 95\% CrI were calculated as the summary statistic for dichotomous variables such as leukopenia, thrombocytopenia, RBC transfusion, PLT transfusion, G-CSF transfusion, and hospitalization.

A random-effects model was utilized in this work to calculate evidence inconsistency as it was believed to be the most suitable and conservative method by which to speculate heterogeneity of various trials within each intervention comparison. The relative ranking of different outcomes was presented as the probabilities. In addition, publication bias was evaluated via observing the symmetry characteristics shown in funnel plots. A symmetrical and concentrated distribution of dots indicates no obvious deviation.

\section{Results}

Baseline characteristics of included studies

The entire process of searching and screening literature was presented in Fig. 1. A total of 1617 potential articles were identified from the databases search. After removing duplicates, 829 publications were screened by reading titles and abstracts. And 36 studies were performed a full-text assessment. Finally, 7 RCTs [18-24] with 1532 patients were enrolled into our analysis. The baseline characteristics of the 7 included studies were presented in Table 1.

The qualities of the eligible studies were assessed according to the Cochrane Collaboration tool for risk of bias assessment. All 7 included studies had strict randomization. Six out of the 7 eligible studies described the randomization process adequately, while the remainder did not explicitly describe the method of sequence generation. Five articles showed detailed information on allocation sequence concealment and the others did not. Meyers et al. have a sophisticated blind design. In the remaining studies, blinding of participants, personnel, and outcome assessment were not clearly stated. In short, most studies had a low risk of attrition and reporting bias. The risk of bias assessment of the eligible RCTs is summarized in Fig. 2.

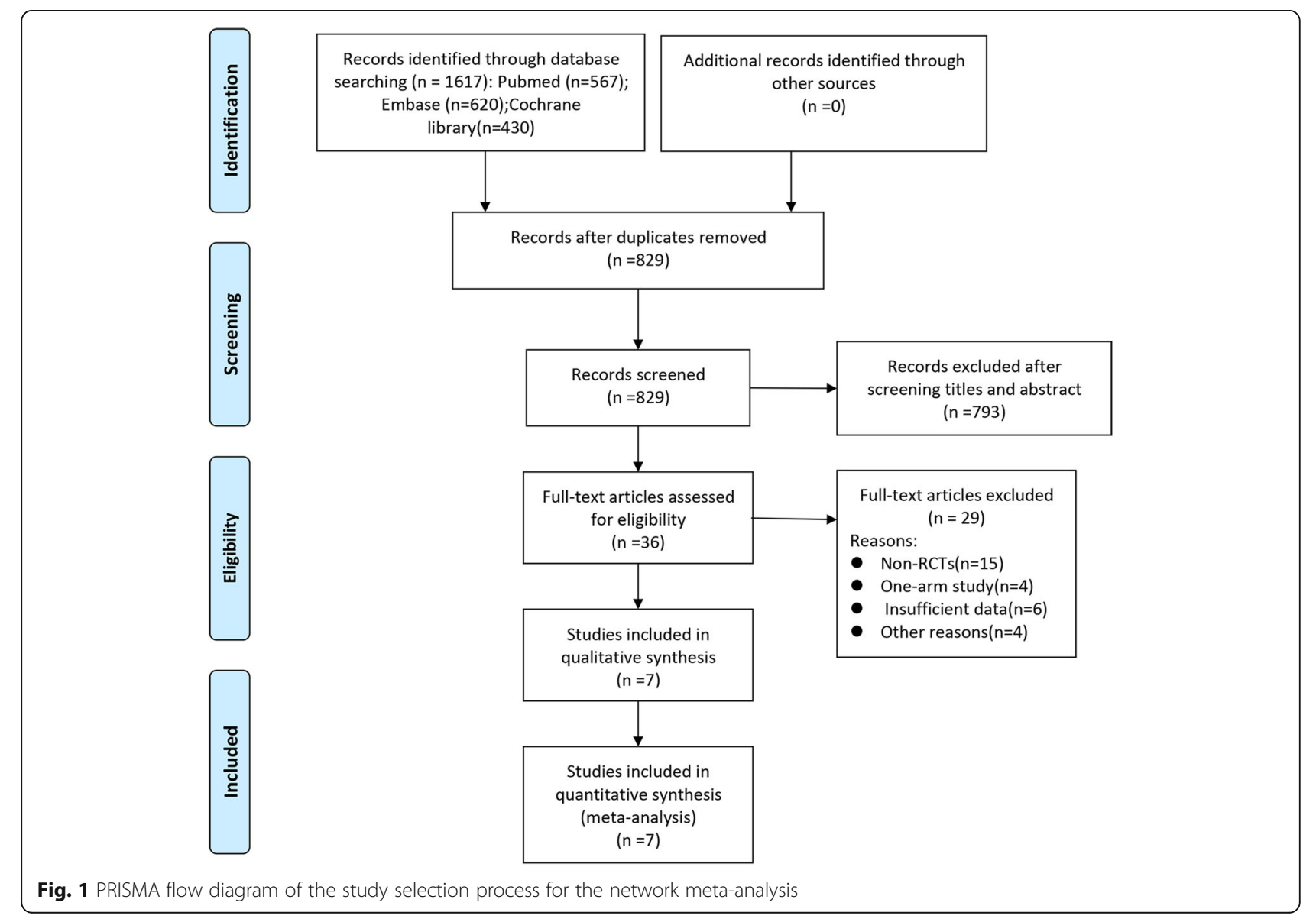


Table 1 Characteristics of the included randomized controlled trials in network meta-analysis

\begin{tabular}{|c|c|c|c|c|c|c|}
\hline Authors, year & Country & $\begin{array}{l}\text { Study } \\
\text { name, } \\
\text { design }\end{array}$ & Experiment group regimens & Control group regimens & $\begin{array}{l}\text { Samples } \\
(E / C)\end{array}$ & $\begin{array}{l}\text { Main } \\
\text { outcomes }\end{array}$ \\
\hline $\begin{array}{l}\text { Craft et al. } \\
2009[22]\end{array}$ & UK & $\begin{array}{l}\text { EOI(80861), } \\
\text { RCT }\end{array}$ & $\begin{array}{l}\text { MTX } 8 \mathrm{~g} / \mathrm{m}^{2} \text { DOX } 25 \mathrm{mg} / \mathrm{m}^{2} \text { daily times } 3 \\
\text { CDP } 100 \mathrm{mg} / \mathrm{m}^{2} 24-\mathrm{h} \text { infusion }\end{array}$ & $\begin{array}{l}\text { DOX } 25 \mathrm{mg} / \mathrm{m}^{2} \text { daily times } 3, \text { CDP } \\
100 \mathrm{mg} / \mathrm{m}^{2} 24-\mathrm{h} \text { infusion }\end{array}$ & $191 / 197$ & $\begin{array}{l}\text { OS, PFS, } \\
\text { severe AEs }\end{array}$ \\
\hline $\begin{array}{l}\text { Whelan et al. } \\
2012 \text { [24] }\end{array}$ & UK & $\begin{array}{l}\text { EOI(80931), } \\
\text { RCT }\end{array}$ & $\begin{array}{l}\text { MTX } 8 \mathrm{~g} / \mathrm{m}^{2} \text { DOX } 75 \mathrm{mg} / \mathrm{m}^{2} \text { CDP } 100 \mathrm{mg} / \mathrm{m}^{2} \\
\text { every } 3 \text { weeks }\end{array}$ & $\begin{array}{l}\text { DOX } 75 \mathrm{mg} / \mathrm{m}^{2} \text { CDP } 100 \mathrm{mg} / \mathrm{m}^{2} \\
\text { every } 3 \text { weeks' }\end{array}$ & $90 / 89$ & $\begin{array}{l}\text { OS, PFS, } \\
\text { severe AEs }\end{array}$ \\
\hline $\begin{array}{l}\text { Ferrari et al. } \\
2012 \text { [23] }\end{array}$ & Italy & $\begin{array}{l}\text { ISG/OS-1, } \\
\text { RCT }\end{array}$ & $\begin{array}{l}\text { MTX } 12 \mathrm{~g} / \mathrm{m}^{2} \text { DOX } 75 \mathrm{mg} / \mathrm{m}^{2} \text { CDP } 120 \mathrm{mg} / \\
\mathrm{m}^{2} \text { IFO } 10 \mathrm{~g} / \mathrm{m}^{2} \text { every } 3 \text { weeks }\end{array}$ & $\begin{array}{l}\text { MTX } 12 \mathrm{~g} / \mathrm{m}^{2} \text { DOX } 75 \mathrm{mg} / \mathrm{m}^{2} \text { CDP } \\
120 \mathrm{mg} / \mathrm{m}^{2} \text { every } 3 \text { weeks' }\end{array}$ & $123 / 123$ & $\begin{array}{l}\text { OS, PFS, } \\
\text { severe AEs }\end{array}$ \\
\hline $\begin{array}{l}\text { Bramwell } \\
\text { et al.1997 [20] }\end{array}$ & Canada & $\mathrm{RCT}$ & $\begin{array}{l}\text { MTX } 8 \mathrm{~g} / \mathrm{m}^{2} \text { DOX } 25 \mathrm{mg} / \mathrm{m}^{2} \text { CDP } 100 \mathrm{mg} / \mathrm{m}^{2} \\
\text { every } 3 \text { weeks }\end{array}$ & $\begin{array}{l}\text { DOX } 25 \mathrm{mg} / \mathrm{m}^{2} \text { CDP } 100 \mathrm{mg} / \mathrm{m}^{2} \\
\text { every } 3 \text { weeks' }\end{array}$ & $13 / 24$ & $\begin{array}{l}\text { OS, PFS, } \\
\text { severe AEs }\end{array}$ \\
\hline $\begin{array}{l}\text { Link et al. } 1991 \\
\text { [18] }\end{array}$ & USA & MIOS, RCT & $\begin{array}{l}\text { MTX } 12 \mathrm{~g} / \mathrm{m}^{2} \text { DOX } 75 \mathrm{mg} / \mathrm{m}^{2} \text { CDP } 120 \mathrm{mg} / \\
\mathrm{m}^{2} \text { IFO } 10 \mathrm{~g} / \mathrm{m}^{2} \text { every } 3 \text { weeks }\end{array}$ & $\begin{array}{l}\text { MTX } 12 \mathrm{~g} / \mathrm{m}^{2} \text { DOX } 75 \mathrm{mg} / \mathrm{m}^{2} \text { CDP } \\
120 \mathrm{mg} / \mathrm{m}^{2} \text { every } 3 \text { weeks }\end{array}$ & $18 / 18$ & $\begin{array}{l}\text { OS, PFS, } \\
\text { severe AEs }\end{array}$ \\
\hline $\begin{array}{l}\text { Bramwell et al. } \\
1992[19]\end{array}$ & Canada & $\mathrm{RCT}$ & $\begin{array}{l}\text { MTX } 8 \mathrm{~g} / \mathrm{m}^{2} \text { DOX } 25 \mathrm{mg} / \mathrm{m}^{2} \mathrm{CDP} 100 \mathrm{mg} / \mathrm{m}^{2} \\
\text { every } 3 \text { weeks }\end{array}$ & $\begin{array}{l}\text { DOX } 25 \mathrm{mg} / \mathrm{m}^{2} \text { CDP } 100 \mathrm{mg} / \mathrm{m}^{2} \\
\text { every } 3 \text { weeks }\end{array}$ & 152/155 & $\begin{array}{l}\text { OS, PFS, } \\
\text { severe AEs }\end{array}$ \\
\hline $\begin{array}{l}\text { Meyers et al. } \\
2005[21]\end{array}$ & USA & $\begin{array}{l}\text { CCG-7921, } \\
\text { RCT }\end{array}$ & $\begin{array}{l}\text { MTX } 12 \mathrm{~g} / \mathrm{m}^{2} \text { DOX } 75 \mathrm{mg} / \mathrm{m}^{2} \text { CDP } 120 \mathrm{mg} / \\
\mathrm{m}^{2} \text { IFO } 9 \mathrm{~g} / \mathrm{m}^{2} \text { every } 3 \text { weeks }\end{array}$ & $\begin{array}{l}\text { MTX } 12 \mathrm{~g} / \mathrm{m}^{2} \text { DOX } 75 \mathrm{mg} / \mathrm{m}^{2} \text { CDP } \\
120 \mathrm{mg} / \mathrm{m}^{2} \text { every } 3 \text { weeks }\end{array}$ & $167 / 172$ & $\begin{array}{l}\text { OS, PFS, } \\
\text { severe AEs }\end{array}$ \\
\hline
\end{tabular}

$R C T$ randomized controlled trial, $M T X$ methotrexate, DOX doxorubicin, CDP cisplatin, IFO ifosfamide, OS overall survival, $P F S$ progression-free survival, $A E s$ adverse events

\section{Network meta-analysis of overall survival}

All studies with 1532 patients provided the HR value or Kaplan-Meier curves for the OS. The direct comparisons between DC, MDC, and MDCI were shown by network plot (Fig. 3). The network meta-analysis results were presented in Table 2. Compared with MDC and DC

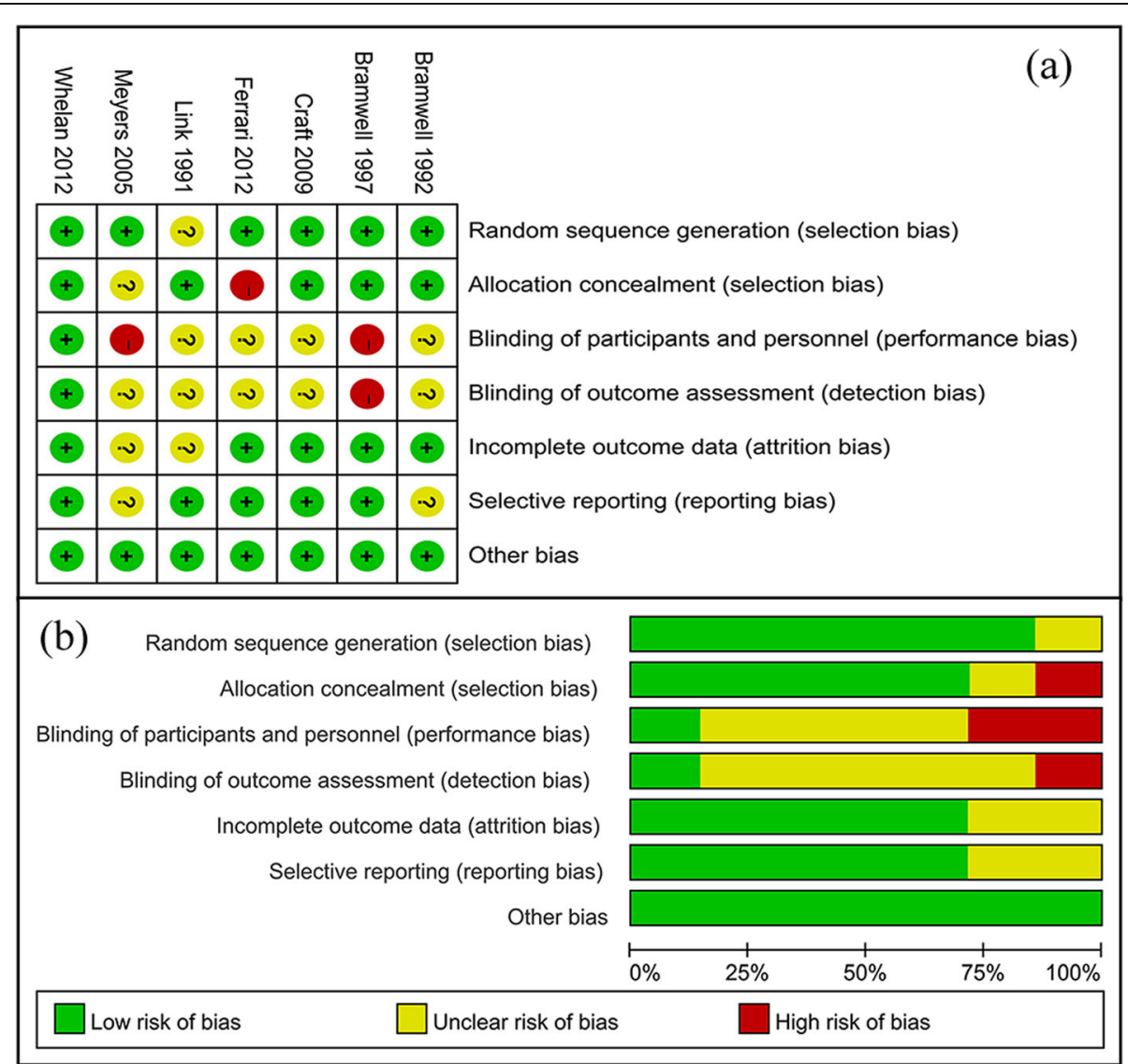

Fig. 2 Risk of bias: graph and summary of the included studies. a Reviewers' judgments of each risk of bias item for eligible studies. $\mathbf{b}$ The judgments of each item of risk of bias, presented as percentages across all eligible studies 
treatment, MDCI had a significant lower hazard risk of overall survival [MDCI vs MDC: $\mathrm{HR}=0.74,95 \% \mathrm{CrI}$ (0.23, 0.87), MDCI vs DC: $\mathrm{HR}=0.60,95 \% \mathrm{CrI}(0.16$, $0.92)$, which meant that MDCI had a longer overall survival time than MDC and DC. For some reason, however, there is no statistically significant between DC and MDC. Meanwhile, probabilities of rank plot (Fig. 4) showed that MDCI ranked first (73.12\%), MDC ranked second (67.41\%), and DC ranked third (72.23\%). Among the interventions, ranked first was the best treatment and the last was worst. The results of ranking analysis were illustrated in Fig. $4 \mathrm{a}$ and Table 3.

\section{Network meta-analysis of progression-free survival}

As for PFS, there were 5 studies with 1249 patients reported the HR value or survival curve. The combined results revealed that MDCI had a clearly longer progression-free survival time than that of DC [MDCI: $\mathrm{HR}=0.88,95 \% \mathrm{CrI}(0.46,0.98)]$. No statistical differences were found in MDC and DC. The network meta-analysis results were illustrated in Table 2. The probabilities of rank plot were as follows: MDCI ranked first (52.43\%), MDC rank second (53.14\%), and DC ranked third (62.77\%). The related ranking results were presented in Fig. $4 \mathrm{~b}$ and Table 3 .

\section{Network meta-analysis of total severe adverse events}

There were 4 studies with 951 patients described the total number of severe adverse events. The pooled results showed that MDCI was associated with a greater total severe AEs than DC [MDCI: OR $=4.69,95 \%$ CrI $(2.79$, 7.87)]. And no significant difference was found between MDC and DC. The analysis results were presented in

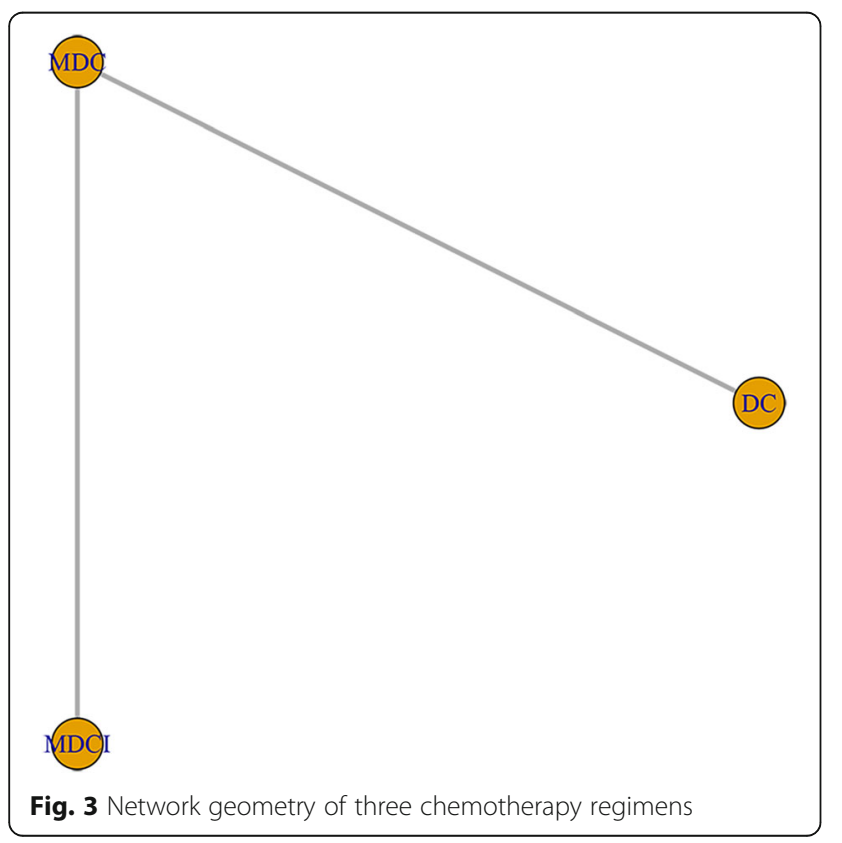

Table 2 The network meta-analysis results of all outcomes

\begin{tabular}{llll}
\hline Outcomes & DC & MDC & MDCl \\
\hline $\begin{array}{l}\text { Overall survival } \\
\text { (HR (95\% Crl)) }\end{array}$ & & \\
DC & 1 & $1.20(0.71,2.43)$ & $1.71(1.47,6.42)$ \\
MDC & $0.81(0.42,1.44)$ & 1 & $1.32(1.04,4.35)$ \\
MDCl & $0.60(0.16,0.92)$ & $0.74(0.23,0.87)$ & 1 \\
Progression-free & & \\
survival (HR (95\% Crl)) & & $1.11(0.63,2.2)$ \\
DC & 1 & $1.12(0.74,1.75)$ & $1.04(0.67,1.7)$ \\
MDC & $0.91(0.60,1.45)$ & 1 & 1 \\
MDCl & $0.88(0.46,0.98)$ & $0.97(0.59,1.51)$ &
\end{tabular}

Total severe

adverse events

(OR $(95 \% \mathrm{Cr})$ )

$\begin{array}{llll}\text { DC } & 1 & 0.56(0.42,0.76) & 0.73(0.44,0.97) \\ \text { MDC } & 1.17(0.64,2.10) & 1 & 0.82(0.42,1.64) \\ \text { MDCl } & 4.69(2.79,7.87) & 2.64(1.73,4.05) & 1\end{array}$

Leukopenia

(OR (95\% Crl))

$\begin{array}{llll}\text { DC } & 1 & 0.45(0.32,0.74) & 0.85(0.54,1.27) \\ \text { MDC } & 1.25(0.64,3.15) & 1 & 0.52(0.12,0.85) \\ \text { MDCl } & 6.69(4.79,9.87) & 2.14(1.33,4.45) & 1\end{array}$

Thrombocytopenia

(OR (95\% Crl))

$\begin{array}{llll}\text { DC } & 1 & 0.76(0.34,0.89) & 0.72(0.41,1.17) \\ \text { MDC } & 2.74(1.64,3.10) & 1 & 0.78(0.39,1.53) \\ \text { MDCl } & 3.14(2.65,7.75) & 2.52(1.85,3.45) & 1\end{array}$

$\mathrm{RBC}$ transfusion

(OR (95\% Crl))

$\begin{array}{llll}\text { DC } & 1 & 0.63(0.31,0.96) & 0.69(0.38,1.54) \\ \text { MDC } & 2.24(0.67,2.85) & 1 & 0.78(0.51,2.44) \\ \text { MDCl } & 4.69(2.79,7.87) & 2.64(1.43,4.05) & 1\end{array}$

PLT transfusion

(OR (95\% Crl))

$\begin{array}{llll}\text { DC } & 1 & 0.57(0.32,0.63) & 0.77(0.54,1.63) \\ \text { MDC } & 1.25(1.03,2.18) & 1 & 0.75(0.38,1.75) \\ \text { MDCl } & 4.41(3.14,5.17) & 1.64(1.03,3.15) & 1\end{array}$

G-CSF (OR (95\% Crl))

$\begin{array}{llll}\text { DC } & 1 & 0.36(0.22,0.85) & 0.71(0.34,1.57) \\ \text { MDC } & 1.43(0.74,3.10) & 1 & 0.81(0.62,1.79) \\ \text { MDCl } & 3.69(2.72,5.87) & 2.94(1.85,3.74) & 1\end{array}$

Hospitalization

(OR (95\% Crl))

$\begin{array}{llll}\mathrm{DC} & 1 & 0.46(0.42,0.76) & 0.69(0.44,2.17) \\ \mathrm{MDC} & 1.10(0.68,2.85) & 1 & 0.76(0.31,1.54) \\ \mathrm{MDCl} & 5.64(2.92,7.52) & 1.38(0.26,3.25) & 1\end{array}$

HR hazard ratio, OR odds ratio, $95 \% \mathrm{Crl} 95 \%$ credible intervals, $R B C$ red blood cell, $P L T$ platelet, G-CSF granulocyte colony-stimulating factor, $D C$ doxorubicin + cisplatin, $M D C$ methotrexate + doxorubicin + cisplatin, $M D C l$ methotrexate + doxorubicin + cisplatin + ifosfamide 


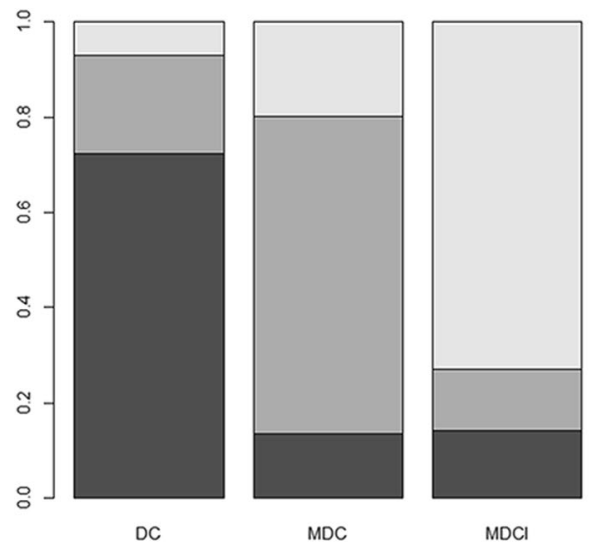

(a) Overall survival

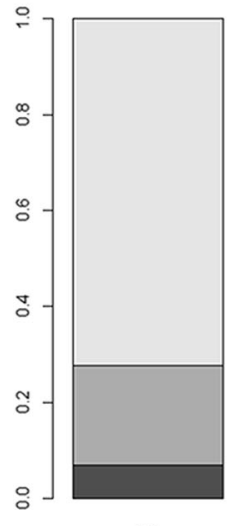

$\mathrm{DC}$

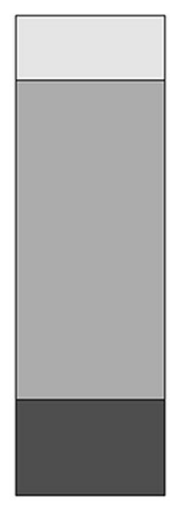

MDC

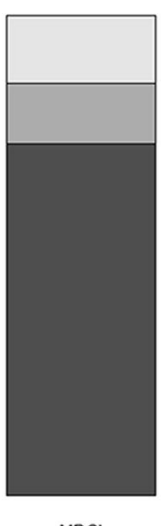

$\mathrm{MDCl}$

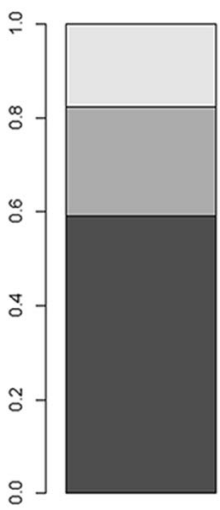

DC

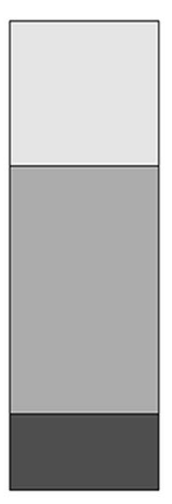

MDC

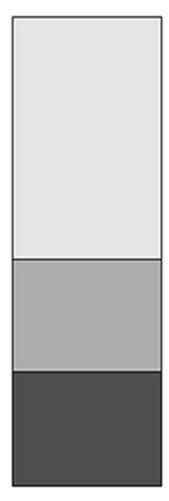

MDCI

(b) Progression-free survival

(c) Total adverse events

Fig. 4 The relevant rank plots based on probabilities of interventions. a Overall survival. b Progression-free survival. c Total severe adverse events

Table 2. Furthermore, the rank results showed that DC ranked first (75.43\%), MDC ranked second (68.17\%), and MDCI ranked third (74.02\%). The results of rank plot analysis were illustrated in Fig. $4 \mathrm{c}$ and Table 3.

\section{Network meta-analysis of severe adverse events}

As for the reported severe AEs in included studies, 6 common events including leukopenia, thrombocytopenia, RBC transfusion, PLT transfusion, G-CSF transfusion, and hospitalization were taken into analysis. The network analysis results are presented in Table 2. Compared with DC, MDCI showed obviously less AEs of leukopenia, thrombocytopenia, RBC transfusion, PLT transfusion, GCSF transfusion, and hospitalization. In addition, MDC was associated with more severe adverse events such as thrombocytopenia and PLT transfusion than DC. Leukopenia is the most common adverse events in the MDCI regimen. No statistical difference was found in the rest of the comparisons.

\section{Consistency and convergence analysis}

Node-splitting analysis was applied to evaluate inconsistency by comparing the differences between direct and indirect evidence. No significant inconsistency was detected among the various treatments, with the $P$ value being less than 0.05 . This meant that the consistency model was reliable. In addition, the potential scale reduction factor (PSRF) was limited to 1 , and our study achieved good convergence efficiency. The publication bias of all outcomes was analysis by funnel plot, and no obvious publish bias was detected.

\section{Discussion}

Osteosarcoma, a rare type of sarcoma, differs greatly in its pathogenesis and biological behavior [25]. About 20$30 \%$ of patients present with metastatic osteosarcoma, most commonly to the lungs, lymph nodes, or other bones [26, 27]. Nowadays, standard treatment of highgrade non-metastatic and metastatic osteosarcoma involves neoadjuvant multiagent chemotherapy followed 
Table 3 Rankings based on simulations

\begin{tabular}{|c|c|c|c|c|}
\hline Endpoints & Ranks & DC & MDC & $\mathrm{MDCl}$ \\
\hline \multirow[t]{3}{*}{ Overall survival (HR (95\% Crl)) } & Rank 1 & 0.07 & 0.20 & 0.73 \\
\hline & Rank 2 & 0.21 & 0.67 & 0.13 \\
\hline & Rank 3 & 0.72 & 0.13 & 0.14 \\
\hline \multirow[t]{3}{*}{ Progression-free survival (HR $(95 \% \mathrm{Crl}))$} & Rank 1 & 0.18 & 0.30 & 0.52 \\
\hline & Rank 2 & 0.23 & 0.53 & 0.24 \\
\hline & Rank 3 & 0.59 & 0.17 & 0.24 \\
\hline \multirow[t]{3}{*}{ Total severe events (OR $(95 \% \mathrm{Crl}))$} & Rank 1 & 0.75 & 0.11 & 0.14 \\
\hline & Rank 2 & 0.20 & 0.68 & 0.12 \\
\hline & Rank 3 & 0.05 & 0.21 & 0.74 \\
\hline \multirow[t]{3}{*}{ Leukopenia (OR (95\% Crl)) } & Rank 1 & 0.69 & 0.12 & 0.18 \\
\hline & Rank 2 & 0.21 & 0.69 & 0.10 \\
\hline & Rank 3 & 0.10 & 0.18 & 0.72 \\
\hline \multirow[t]{3}{*}{ Thrombocytopenia (OR (95\% Crl)) } & Rank 1 & 0.72 & 0.14 & 0.14 \\
\hline & Rank 2 & 0.20 & 0.73 & 0.07 \\
\hline & Rank 3 & 0.07 & 0.13 & 0.79 \\
\hline \multirow[t]{3}{*}{ RBC transfusion (OR (95\% Crl)) } & Rank 1 & 0.55 & 0.31 & 0.14 \\
\hline & Rank 2 & 0.30 & 0.43 & 0.27 \\
\hline & Rank 3 & 0.15 & 0.25 & 0.60 \\
\hline \multirow[t]{3}{*}{ PLT transfusion (OR $(95 \% \mathrm{Crl}))$} & Rank 1 & 0.63 & 0.20 & 0.17 \\
\hline & Rank 2 & 0.19 & 0.58 & 0.22 \\
\hline & Rank 3 & 0.19 & 0.21 & 0.59 \\
\hline \multirow[t]{3}{*}{ G-CSF (OR $(95 \%$ Crl)) } & Rank 1 & 0.71 & 0.12 & 0.17 \\
\hline & Rank 2 & 0.22 & 0.67 & 0.11 \\
\hline & Rank 3 & 0.07 & 0.20 & 0.73 \\
\hline \multirow[t]{3}{*}{ Hospitalization (OR (95\% Crl)) } & Rank 1 & 0.74 & 0.10 & 0.16 \\
\hline & Rank 2 & 0.21 & 0.69 & 0.10 \\
\hline & Rank 3 & 0.05 & 0.21 & 0.74 \\
\hline
\end{tabular}

$H R$ hazard ratio, OR odds ratio, $95 \% \mathrm{Crl} 95 \%$ credible intervals, $R B C$ red blood cell, PLT platelet, G-CSF granulocyte colony-stimulating factor, $D C$ doxorubicin + cisplatin, $M D C$ methotrexate + doxorubicin + cisplatin, $M D C l$ methotrexate + doxorubicin + cisplatin + ifosfamide

by surgical resection of the lesions and adjuvant multiagent sequential chemotherapy [28, 29]. As the survival rate increases from 20 to $80 \%$, chemotherapy for treatment of osteosarcoma was demonstrated to be effective [30]. The efficacy of frontline chemotherapy agents (high-dose methotrexate, doxorubicin, cisplatin, and ifosfamide in the treatment of osteosarcoma) has been investigated; however, results are inconsistent.

This study is a network meta-analysis with the objective of assessing the efficacy and safety of first-line chemotherapeutic agents for osteosarcoma. In our study, 7 high-quality RCTs with 1532 patients were included and analyzed. The efficacy was assessed by the outcomes of OS, PFS. In addition, we evaluated the safety through total number of severe AEs and several common related AEs. Based on the results of the analysis, we found that the regimen MDCI could significantly increase OS, PFS, and severe AEs compared with DC. Furthermore, MDCI had a significant lower hazard risk of OS than MDC. While, there was no significant difference in PFS for MDCI and MDC. The efficacy of MDCI has been proven in the trails of Ferrari, Link and Meyers [18, 21, 23]. According to the ranking results, MDCI ranked first in OS and PFS. Regarding safety outcomes, however, MDCI was ranked third after MDC and DC. There were no direct comparisons of MDCI and DC. The relationship between MDCI and DC, however, was obtained by indirect comparisons in our study. According to the results, methotrexate and ifosfamide may contribute to the chemotherapy approach.

Methotrexate (MTX) seems to be one of the most active agents, however, at the moment, it is not clear about the absolute role of it in multidrug chemotherapy [10, 11]. In the literature, the use of MTX in osteosarcoma from the initial single-agent to the complex combination regimens can be found. Rosen et al. [31] measured the tumor response at the time of surgery to assess the efficacy of preoperative MTX. A good histologic response with >90\% tumor necrosis was observed in 25 of 32 (78\%) patients with primary disease after four weekly doses of $8-12 \mathrm{~g} / \mathrm{m}^{2}$ $[31,32]$. The response rate of the combination of MTX has not been clearly defined [33]. Bramwell et al. [19] conducted a RCT comparing 2 chemotherapy schemes: DC versus high dose MTX with reduced dose doxorubicin and cisplatin. PFS was inferior in patients who received the 3drug arm but OS was not significantly different between both treatment arms. Bacci et al. [34] demonstrated that patients receiving MTX had a significant lower hazard risk of overall survival rates at 5 years. These results confirmed the significant survival benefits of methotrexate-based chemotherapy for osteosarcoma. These findings are similar to our network meta-analysis results.

Ifosfamide, an alkylating agent, works by disrupting the tumor cell's microtubule dynamics, was introduced approximately 20 years later [35]. As an analog of cyclophosphamide, it is highly active in the treatment of osteosarcoma [36]. In a phase II study of ifosfamide in the treatment of recurrent sarcomas in young people concluded by Magrath et al. [37], patients who experienced relapse after standard therapies have shown remarkable responses when they were subjected to ifosfamide-based chemotherapy. In the meta-analysis of Fan et al. [38], ifosfamide-based chemotherapy reduced the risk of death in patients with osteosarcoma by $17 \%$ $(\mathrm{HR}=0.83,95 \%$ CrI 0.70, 0.99; $P=0.034)$. Meta-analysis, the highest level of evidence, showed the efficacy of ifosfamide for osteosarcoma. Therefore, the role of ifosfamide in the MDCI regimen may contribute to the chemotherapy advantage compared with MDC.

Even though multidrug regimens, such as MDCI and $\mathrm{MDC}$, had a better effect on prolonging the PFS and OS 
of osteosarcoma patients, it should be recognized the serious adverse effects [39]. According to our results, that MDCI was associated with a greater total severe AEs than DC [MDCI: OR $=4.69,95 \% \operatorname{CrI}(2.79,7.87)]$. Serious adverse effects such as leukopenia and thrombocytopenia will affect the application of the regimens and even the quality of life of patients [40, 41]. The reduction of adverse events is a direction for the wide application of multidrug chemotherapy [42, 43].

In recent years, studies co-sponsored by European and American Osteosarcoma Studies (EURAMOS), Cooperative Osteosarcoma Study Group (COSS), European Osteosarcoma Intergroup (EOI), and Scandinavian Sarcoma Group (SSG) have yielded encouraging results [44-46]. Smeland et al. [44] enrolled 2186 patients over a 6-year period and evaluated their differences after receiving MDC chemotherapy. As their conclusions show, nearly 4 out of every 5 patients with non-metastatic osteosarcoma who have all disease resected and MDC finished are alive 5 years later, and the risk of relapse appears to decrease over time. Since their study did not directly compare MDC and MDCI, their data was not suitable for inclusion in our work.

Neoadjuvant and adjuvant chemotherapy combined with resection has become the basic strategy for the treatment of osteosarcoma [47]. Neoadjuvant chemotherapy includes the addition of chemotherapy drugs before resection, and this regimen has the following advantages: (1) It can control the primary tumor and reduce the chance of surgical tumor invasion. (2) It can eliminate micrometastasis early and avoid metastasis caused by delayed surgery or low resistance. (3) It can evaluate the effect of chemotherapy and guide comprehensive treatment after surgery. (4) It can assess the prognosis earlier. Although the results of RCTs suggested no significant effect on the outcome of patients when comparing preoperative chemotherapy to postoperative chemotherapy [48], neoadjuvant chemotherapy for limb salvage and the surgical process is still worthy of clinical application. Independent comparisons and discussions of neoadjuvant chemotherapy and adjuvant chemotherapy were not mentioned in our study. As we know, the resistance of chemotherapy does not change with or without surgery [49]. A large number of studies have confirmed that MDCI shows the same efficacy in neoadjuvant chemotherapy and adjuvant chemotherapy $[24,50]$.

The extent of histologic response may have an impact on the EFS outcome. Patients with $>90 \%$ tumor necrosis were classified as good responders (GRs), whereas patients with $<90 \%$ were defined as poor responders (PRs). In the study conducted by Ferrari et al. [23], 5-year EFS was 69\% (95\% CrI, 60 to $78 \%$ ) for GRs and 52\% (95\% CrI, 44 to $61 \%$ ) for PRs. The purpose of our study was to briefly evaluate the efficacy of four chemotherapeutic drugs (high-dose methotrexate, cisplatin, doxorubicin, and ifosfamide) prescribed in the NCNC Guidelines for patients with osteosarcoma. The regrouping and discussion based on the histologic response of patients were not covered, so we can draw a conclusion that is applicable to primary hospitals (inability to evaluate tumor necrosis after surgery), especially in developing countries like China [51]. We hope that our study with the statistical advantage of meta-analysis can provide a concise guide for chemotherapy of osteosarcoma.

There were methodological strengths in our study as follows: (1) comprehensive retrieval strategy was applied to reduce the risk of publication bias; (2) the application of rank plot can distinguish subtle differences among all chemotherapy agents; and (3) the study was the first comparison of direct and indirect approaches, which incorporated all available data to evaluate the interventions more precisely.

Nevertheless, our meta-analysis does have certain limitations. First of all, no direct comparison between MDCI and DC was found and included, which may have caused inaccurate results in our analysis. In order to avoid interference with other agents, our analysis only included trials that their regimen is any combination of methotrexate, doxorubicin, cisplatin, and ifosfamide. Therefore, many RCTs containing irrelevant agents such as vincristine and actinomycin-D were excluded. Secondly, for some included RCTs, the detailed blind methods and allocation concealment were not described which could affect the validity for overall findings. Thirdly, we just analyzed nine types of outcomes from the variable endpoints. This could miss several necessary outcomes and affect the whole analysis results.

\section{Conclusion}

MDCI showed its superiority among all chemotherapeutic regimens in relation to efficacy and safety, followed by MDC. In addition, MDCI was associated with an increased risk of AEs. According to our analysis, DC was less effective but safer for MDC and MDCI. Therefore, we recommended MDCI as the optimal choice for osteosarcoma. However, considering limitations of our network meta-analysis, additional high-quality studies are needed for further evaluation.

\section{Abbreviations \\ 95\% Crl: 95\% credible intervals; C: Cisplatin; D: Doxorubicin; DC: Doxorubicin + cisplatin; G-CSF: Granulocyte colony-stimulating factor; HR: Hazard ratio; I: Ifosfamide; M: Methotrexate; MDC: Methotrexate + doxorubicin + cisplatin; MDCl: Methotrexate + doxorubicin + cisplatin + ifosfamide; OR: Odds ratio; PLT: Platelet; RBC: Red blood cell}

\section{Acknowledgements}

The authors thank the School of Medical Sciences, Zhengzhou University, for the technical guidance.

Authors' contributions

BZ participated in conception and design of this study. YZ, RL, JL, and XL performed the acquisition of data. BZ and YZ performed the statistical analyses. LZ was involved in the interpretation of data. BZ drafted the manuscript. All authors read and approved the final manuscript. 


\section{Funding}

This work was supported by the Science and Technology Program of Henan Province (no. 182102310370, 192102310389).

\section{Availability of data and materials}

All data generated or analyzed during this study are included in this published article.

\section{Ethics approval and consent to participate}

All analyses were based on previous published studies; thus, no ethical approval and patient consent are required.

\section{Consent for publication}

Not applicable

\section{Competing interests}

The authors declare that they have no competing interests.

\section{Author details}

'Department of Orthopedics, The First Affiliated Hospital of Zhengzhou University, No. 1 Jian she East Road, Erqi District, Zhengzhou City 450052, Henan Province, People's Republic of China. ${ }^{2}$ Department of Oncology, Sun Yat-Sen University Cancer Center, State Key Laboratory of Oncology in South China, Collaborative Innovation Center for Cancer Medicine, No. 651 Dongfeng East Road, Guangzhou 510060, Guangdong, People's Republic of China.

\section{Received: 7 October 2019 Accepted: 30 January 2020}

\section{Published online: 13 February 2020}

\section{References}

1. Kumar R, Kumar M, Malhotra K, Patel S. Primary osteosarcoma in the elderly revisited: current concepts in diagnosis and treatment. Curr Oncol Rep. 2018;20(2):13. https://doi.org/10.1007/s11912-018-0658-1.

2. Harrison DJ, Geller DS, Gill JD, Lewis VO, Gorlick R. Current and future therapeutic approaches for osteosarcoma. Expert Rev Anticancer Ther. 2018; 18(1):39-50. https://doi.org/10.1080/14737140.2018.1413939.

3. Mirabello L, Troisi RJ, Savage SA. International osteosarcoma incidence patterns in children and adolescents, middle ages and elderly persons. Int J Cancer. 2009;125(1):229-34. https://doi.org/10.1002/ijc.24320.

4. Aljubran AH, Griffin A, Pintilie M, Blackstein M. Osteosarcoma in adolescents and adults: survival analysis with and without lung metastases. Ann Oncol. 2009;20(6):1136-41. https://doi.org/10.1093/annonc/mdn731.

5. Shaikh AB, Li F, Li M, He B, He X, Chen G, Guo B, Li D, Jiang F, Dang L, Zheng S, Liang C, Liu J, Lu C, Liu B, Lu J, Wang L, Lu A, Zhang G. Present advances and future perspectives of molecular targeted therapy for osteosarcoma. Int J Mol Sci. 2016;17(4):506. https://doi.org/10.3390/ ijms17040506.

6. Zhang Y, Yang J, Zhao N, Wang C, Kamar S, Zhou Y, He Z, Yang J, Sun B, Shi $X$, Han L, Yang Z. Progress in the chemotherapeutic treatment of osteosarcoma. Oncol Lett. 2018;16(5):6228-37. https://doi.org/10.3892/ol. 2018.9434.

7. Wunder JS, Nielsen TO, Maki RG, O'Sullivan B, Alman BA. Opportunities for improving the therapeutic ratio for patients with sarcoma. Lancet Oncol. 2007:8(6):513-24. https://doi.org/10.1016/s1470-2045(07)70169-9.

8. Biermann JS, Chow W, Reed DR, Lucas D, Adkins DR, Agulnik M, Benjamin RS, Brigman B, Budd GT, Curry WT, Didwania A, Fabbri N, Hornicek FJ, Kuechle JB, Lindskog D, Mayerson J, McGarry SV, Million L, Morris CD, Movva S, O'Donnell RJ, Randall RL, Rose P, Santana VM, Satcher RL, Schwartz H, Siegel HJ, Thornton K, Villalobos V, Bergman MA, Scavone JL. NCCN Guidelines insights: bone cancer, version 2.2017. J Natl Compr Cancer Netw. 2017;15(2):155-67. https://doi.org/10.6004/jnccn.2017.0017.

9. Lugowska I, Pienkowski A, Szumera-Cieckiewicz A, Kosela-Paterczyk H, Teterycz P, Glogowski M, Kozak K, Klimczak A, Falkowski S, Rutkowski P. The long-term treatment outcomes of adult osteosarcoma. Polski Merkuriusz Lekarski. 2017:42(250):158-64

10. Grem JL, King SA, Wittes RE, Leyland-Jones B. The role of methotrexate in osteosarcoma. J Natl Cancer Inst. 1988;80(9):626-55. https://doi.org/10.1093/ jnci/80.9.626.

11. Edmonson JH. High-dose methotrexate in osteosarcoma--Mayo Clinic studies. NCl Monogr. 1987;5:67-9.
12. Janeway KA, Grier HE. Sequelae of osteosarcoma medical therapy: a review of rare acute toxicities and late effects. Lancet Oncol. 2010;11(7):670-8. https://doi.org/10.1016/s1470-2045(10)70062-0.

13. Ferrari S, Serra M. An update on chemotherapy for osteosarcoma. Expert Opin Pharmacother. 2015;16(18):2727-36. https://doi.org/10.1517/14656566. 2015.1102226.

14. Yamamoto $\mathrm{N}$, Tsuchiya $\mathrm{H}$. Chemotherapy for osteosarcoma - where does it come from? What is it? Where is it going? Expert Opin Pharmacother. 2013; 14(16):2183-93. https://doi.org/10.1517/14656566.2013.827171.

15. Kubo T, Shimose S, Fujimori J, Furuta T, Ochi M. Quantitative (201) thallium scintigraphy for prediction of histological response to neoadjuvant chemotherapy in osteosarcoma; systematic review and meta-analysis. Surg Oncol. 2015:24(3):194-9. https://doi.org/10.1016/j.suronc.2015.06.009.

16. Tierney JF, Stewart LA, Ghersi D, Burdett S, Sydes MR. Practical methods for incorporating summary time-to-event data into meta-analysis. Trials. 2007:8: 16. https://doi.org/10.1186/1745-6215-8-16.

17. Parmar MK, Torri $V$, Stewart L. Extracting summary statistics to perform meta-analyses of the published literature for survival endpoints. Stat Med. 1998:17(24):2815-34. https://doi.org/10.1002/(sici)1097-0258(19981230)17: 24<2815::aid-sim110>3.0.co;2-8.

18. Link MP, Goorin AM, Horowitz M, Meyer WH, Belasco J, Baker A, Ayala A Shuster J. Adjuvant chemotherapy of high-grade osteosarcoma of the extremity. Updated results of the Multi-Institutional Osteosarcoma Study. Clin Orthopaedics Related Res. 1991;270:8-14.

19. Bramwell VH, Burgers $M$, Sneath $R$, Souhami $R$, van Oosterom AT, Voute PA, Rouesse J, Spooner D, Craft AW, Somers R, et al. A comparison of two short intensive adjuvant chemotherapy regimens in operable osteosarcoma of limbs in children and young adults: the first study of the European Osteosarcoma Intergroup. J Clin Oncol. 1992;10(10):1579-91. https://doi.org/ 10.1200/jco.1992.10.10.1579.

20. Bramwell VH, Burgers MV, Souhami RL, Taminiau AH, Van Der Eijken JW, Craft AW, Malcolm AJ, Uscinska B, Kirkpatrick AL, Machin D, Van Glabbeke MM. A randomized comparison of two short intensive chemotherapy regimens in children and young adults with osteosarcoma: results in patients with metastases: a study of the European Osteosarcoma Intergroup. Sarcoma. 1997:1(3-4):155-60. https://doi.org/10.1080/ 13577149778245.

21. Meyers PA, Schwartz CL, Krailo M, Kleinerman ES, Betcher D, Bernstein ML Conrad E, Ferguson W, Gebhardt M, Goorin AM, Harris MB, Healey J, Huvos A, Link M, Montebello J, Nadel H, Nieder M, Sato J, Siegal G, Weiner M, Wells R, Wold L, Womer R, Grier H. Osteosarcoma: a randomized, prospective trial of the addition of ifosfamide and/or muramyl tripeptide to cisplatin, doxorubicin, and high-dose methotrexate. J Clin Oncol. 2005;23(9): 2004-11. https://doi.org/10.1200/jco.2005.06.031

22. Craft AW. Osteosarcoma: the European Osteosarcoma Intergroup (EOI) perspective. Cancer Treat Res. 2009;152:263-74. https://doi.org/10.1007/9781-4419-0284-9_13.

23. Ferrari S, Ruggieri P, Cefalo G, Tamburini A, Capanna R, Fagioli F, Comandone A, Bertulli R, Bisogno G, Palmerini E, Alberghini M, Parafioriti A, Linari A, Picci P, Bacci G. Neoadjuvant chemotherapy with methotrexate, cisplatin, and doxorubicin with or without ifosfamide in nonmetastatic osteosarcoma of the extremity: an Italian sarcoma group trial ISG/OS-1. Clin Oncol. 2012;30(17):2112-8. https://doi.org/10.1200/jco.2011.38.4420.

24. Whelan JS, Jinks RC, McTiernan A, Sydes MR, Hook JM, Trani L, Uscinska B, Bramwell V, Lewis IJ, Nooij MA, van Glabbeke M, Grimer RJ, Hogendoorn PC Taminiau AH, Gelderblom H. Survival from high-grade localised extremity osteosarcoma: combined results and prognostic factors from three European Osteosarcoma Intergroup randomised controlled trials. Ann Oncol. 2012;23(6):1607-16. https://doi.org/10.1093/annonc/mdr491.

25. Marina N, Gebhardt M, Teot L, Gorlick R. Biology and therapeutic advances for pediatric osteosarcoma. Oncologist. 2004;9(4):422-41. https://doi.org/10. 1634/theoncologist.9-4-422.

26. Kaste SC, Pratt CB, Cain AM, Jones-Wallace DJ, Rao BN. Metastases detected at the time of diagnosis of primary pediatric extremity osteosarcoma at diagnosis: imaging features. Cancer. 1999;86(8):1602-8. https://doi.org/10. 1002/(sici)1097-0142(19991015)86:8<1602::aid-cncr31>3.0.co;2-r.

27. Geller DS, Gorlick R. Osteosarcoma: a review of diagnosis, management, and treatment strategies. Clin Adv Hematol Oncol. 2010;8(10):705-18.

28. Chou AJ, Gorlick R. Chemotherapy resistance in osteosarcoma: current challenges and future directions. Expert Rev Anticancer Ther. 2006;6(7): 1075-85. https://doi.org/10.1586/14737140.6.7.1075. 
29. Johal S, Ralston S, Knight C. Mifamurtide for high-grade, resectable, nonmetastatic osteosarcoma following surgical resection: a costeffectiveness analysis. Value Health. 2013;16(8):1123-32. https://doi.org/10. 1016/j.jval.2013.08.2294.

30. Jaffe N. Historical perspective on the introduction and use of chemotherapy for the treatment of osteosarcoma. Adv Exp Med Biol. 2014;804:1-30. https://doi.org/10.1007/978-3-319-04843-7_1

31. Rosen G, Marcove RC, Caparros B, Nirenberg A, Kosloff C, Huvos AG. Primary osteogenic sarcoma: the rationale for preoperative chemotherapy and delayed surgery. Cancer. 1979;43(6):2163-77. https://doi.org/10.1002/10970142(197906)43:6<2163::aid-cncr2820430602>3.0.co;2-s.

32. Hanafy E, Al Jabri A, Gadelkarim G, Dasaq A, Nazim F, Al Pakrah M. Tumor histopathological response to neoadjuvant chemotherapy in childhood solid malignancies: is it still impressive? J Investigative Med. 2018;66(2):28997. https://doi.org/10.1136/jim-2017-000531.

33. Marsden FW, Stephens FO, McCarthy SW, Ferrari AM. IIB osteosarcoma. Current management, local control, and survival statistics--the Australian experience. Clin Orthop Related Res. 1991;270:113-9.

34. Bacci G, Picci P, Ruggieri P, Mercuri M, Avella M, Capanna R, Brach Del Prever A, Mancini A, Gherlinzoni F, Padovani G, et al. Primary chemotherapy and delayed surgery (neoadjuvant chemotherapy) for osteosarcoma of the extremities. The Istituto Rizzoli experience in 127 patients treated preoperatively with intravenous methotrexate (high versus moderate doses) and intraarterial cisplatin. Cancer. 1990;65(11):2539-53. https://doi.org/10. 1002/1097-0142(19900601)65:11<2539::aid-cncr2820651125>3.0.co;2-m.

35. Sutow WW, Sullivan MP, Fernbach DJ, Cangir A, George SL. Adjuvant chemotherapy in primary treatment of osteogenic sarcoma. A Southwest Oncology Group study. Cancer. 1975;36(5):1598-602. https://doi.org/10. 1002/1097-0142(197511)36:5<1598:.:aid-cncr2820360511>3.0.co;2-n.

36. Robinson D, Schulz G, Langley R, Donze K, Winchester K, Rodgers C. Evidence-based practice recommendations for hydration in children and adolescents with cancer receiving intravenous cyclophosphamide. J Pediatric Oncol Nurs. 2014;31(4):191-9. https://doi.org/10.1177/ 1043454214532024.

37. Magrath I, Sandlund J, Raynor A, Rosenberg S, Arasi V, Miser J. A phase II study of ifosfamide in the treatment of recurrent sarcomas in young people. Cancer Chemother Pharmacol. 1986;18(Suppl 2):S25-8. https://doi. org/10.1007/bf00647446.

38. Fan XL, Cai GP, Zhu LL, Ding GM. Efficacy and safety of ifosfamide-based chemotherapy for osteosarcoma: a meta-analysis. Drug Des Devel Ther. 2015;9:5925-32. https://doi.org/10.2147/dddt.s91217.

39. van Dalen EC, van As JW, de Camargo B (2011) Methotrexate for high-grade osteosarcoma in children and young adults. Cochrane Database Systematic Reviews (5):Cd006325. doi:https://doi.org/10.1002/14651858.CD006325.pub3.

40. Chou AJ, Kleinerman ES, Krailo MD, Chen Z, Betcher DL, Healey JH, Conrad EU 3rd, Nieder ML, Weiner MA, Wells RJ, Womer RB, Meyers PA. Addition of muramyl tripeptide to chemotherapy for patients with newly diagnosed metastatic osteosarcoma: a report from the Children's Oncology Group. Cancer. 2009:115(22):5339-48. https://doi.org/10.1002/cncr.24566.

41. Meyers PA, Schwartz CL, Krailo MD, Healey JH, Bernstein ML, Betcher D, Ferguson WS, Gebhardt MC, Goorin AM, Harris M, Kleinerman E, Link MP, Nadel H, Nieder M, Siegal GP, Weiner MA, Wells RJ, Womer RB, Grier HE. Osteosarcoma: the addition of muramyl tripeptide to chemotherapy improves overall survival--a report from the Children's Oncology Group. J Clin Oncol. 2008:26(4):633-8. https://doi.org/10.1200/jco.2008.14.0095.

42. Frampton JE. Mifamurtide: a review of its use in the treatment of osteosarcoma. Paediatric Drugs. 2010;12(3):141-53. https://doi.org/10.2165/ 11204910-000000000-00000.

43. Solomon DH, Rekedal L, Cadarette SM. Osteoporosis treatments and adverse events. Curr Opin Rheumatol. 2009;21(4):363-8. https://doi.org/10. 1097/BOR.0b013e32832ca433.

44. Smeland S, Bielack SS, Whelan J, Bernstein M, Hogendoorn P, Krailo MD, Gorlick R, Janeway KA, Ingleby FC, Anninga J, Antal I, Arndt C, Brown KLB, Butterfass-Bahloul T, Calaminus G, Capra M, Dhooge C, Eriksson M, Flanagan AM, Friedel G, Gebhardt MC, Gelderblom H, Goldsby R, Grier HE, Grimer R, Hawkins DS, Hecker-Nolting S, Sundby Hall K, Isakoff MS, Jovic G, Kuhne T, Kager L, von Kalle T, Kabickova E, Lang S, Lau CC, Leavey PJ, Lessnick SL, Mascarenhas L, Mayer-Steinacker R, Meyers PA, Nagarajan R, Randall RL, Reichardt P, Renard M, Rechnitzer C, Schwartz CL, Strauss S, Teot L, Timmermann B, Sydes MR, Marina N. Survival and prognosis with osteosarcoma: outcomes in more than 2000 patients in the EURAMOS-1
(European and American Osteosarcoma Study) cohort. Eur J Cancer. 2019; 109:36-50. https://doi.org/10.1016/j.ejca.2018.11.027.

45. Brard C, Piperno-Neumann S, Delaye J, Brugieres L, Hampson LV, Le Teuff G, Le Deley MC, Gaspar N. Sarcome-13/OS2016 trial protocol: a multicentre, randomised, open-label, phase II trial of mifamurtide combined with postoperative chemotherapy for patients with newly diagnosed high-risk osteosarcoma. BMJ Open. 2019;9(5):e025877. https://doi.org/10.1136/ bmjopen-2018-025877.

46. Lancia C, Anninga JK, Sydes MR, Spitoni C, Whelan J, Hogendoorn PCW, Gelderblom H, Fiocco M. A novel method to address the association between received dose intensity and survival outcome: benefits of approaching treatment intensification at a more individualised level in a trial of the European Osteosarcoma Intergroup. Cancer Chemother Pharmacol. 2019;83(5):951-62. https://doi.org/10.1007/s00280-019-03797-3.

47. Wang $X$, Zheng H, Shou T, Tang C, Miao K, Wang P. Effectiveness of multidrug regimen chemotherapy treatment in osteosarcoma patients: a network meta-analysis of randomized controlled trials. J Orthop Surg Res. 2017;12(1):52. https://doi.org/10.1186/s13018-017-0544-9.

48. Goorin AM, Schwartzentruber DJ, Devidas M, Gebhardt MC, Ayala AG, Harris MB, Helman LJ, Grier HE, Link MP. Presurgical chemotherapy compared with immediate surgery and adjuvant chemotherapy for nonmetastatic osteosarcoma: Pediatric Oncology Group Study POG-8651. J Clin Oncol. 2003;21(8):1574-80. https://doi.org/10.1200/jco.2003.08.165.

49. Riesco-Martinez M, Parra K, Saluja R, Francia G, Emmenegger U. Resistance to metronomic chemotherapy and ways to overcome it. Cancer Lett. 2017; 400:311-8. https://doi.org/10.1016/j.canlet.2017.02.027.

50. Ferrari S, Meazza C, Palmerini E, Tamburini A, Fagioli F, Cozza R, Ferraresi V, Bisogno G, Mascarin M, Cefalo G, Manfrini M, Capanna R, Biagini R, Donati D, Picci P. Nonmetastatic osteosarcoma of the extremity. Neoadjuvant chemotherapy with methotrexate, cisplatin, doxorubicin and ifosfamide. An Italian Sarcoma Group study (ISG/OS-Oss). Tumori. 2014;100(6):612-9. https://doi.org/10.1700/1778.19262.

51. Zhang SP, Li X, Li H, Sun XH, Yan XF. Significance of neoadjuvant chemotherapy (NACT) in limb salvage treatment of osteosarcoma and its effect on GLS1 expression. Eur Review Med Pharmacol Sci. 2018;22(19): 6538-44. https://doi.org/10.26355/eurrev_201810_16067.

\section{Publisher's Note}

Springer Nature remains neutral with regard to jurisdictional claims in published maps and institutional affiliations.
Ready to submit your research? Choose BMC and benefit from:
- fast, convenient online submission
- thorough peer review by experienced researchers in your field
- rapid publication on acceptance
- support for research data, including large and complex data types
- gold Open Access which fosters wider collaboration and increased citations
- maximum visibility for your research: over $100 \mathrm{M}$ website views per year
At BMC, research is always in progress.
Learn more biomedcentral.com/submissions 